\title{
Seed production of bush snap beans genotypes in conventional and organic systems
}

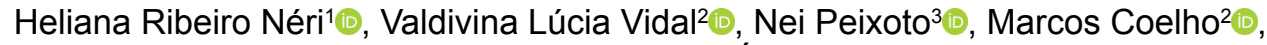 \\ Ruanny Karen Vidal Pantoja Portal Moreira ${ }^{4}{ }^{\oplus}$, Érica Fernandes Leão-Araujo ${ }^{[}$

\footnotetext{
${ }^{1}$ Escola Família Agrícola de Orizona, Orizona-GO, Brasil. E-mail: hrn10@live.com

${ }^{2}$ Emater, Estação Experimental de Anápolis, Anápolis-GO, Brasil. E-mail: luciavidalc@yahoo.com.br; mcoelho@emater.go.gov.br

${ }^{3}$ Universidade Estadual de Goiás, Unidade Universitária de Ipameri, Ipameri-GO, Brasil. E-mail: nei.peixoto48@gmail.com

${ }^{4}$ Universidade Federal do Pará, Programa de Pós-Graduação em Biodiversidade e Biotecnologia da Rede Bionorte, Belém-PA, Brasil. E-mail: ruanny_vidal@hotmail.com

${ }^{5}$ Instituto Federal Goiano, Campus Urutaí, Urutaí-GO, Brasil. E-mail: erica.leao@ifgoiano.edu.br
}

ABSTRACT: Snap beans are one of the ten most consumed vegetables in Brazil, and there are few cultivars available in the Brazilian market. This study aimed to evaluate the seed yield of 20 snap beans genotypes under conventional and organic systems under Brazilian Cerrado conditions. Plant height, number of seeds per pod, weight of 100 seeds and yield were evaluated. For plant height and number of seeds per pod, the 20 genotypes were equal in the conventional cultivation system. In the organic system, the 20 genotypes formed two distinct groups regarding these variables. In the conventional system there were no significant differences between genotypes regarding the weight of 100 seeds, the mean mass in this system was 19.08 $\mathrm{g}$, but there were differences in the organic system. Regarding yield, there was significant difference between the genotypes for both cultivation systems, organic and convetional. Production of snap bean cultivars in the organic system was shown as viable and promising. The genotypes Amarelo Japonês, Hab 1 and Tendergreen Improved stood out among the most productive in both systems.

\section{Produção de sementes de genótipos arbustivos de feijão-vagem nos sistemas convencional e orgânico}

RESUMO: O feijão-vagem, é uma das dez hortaliças mais consumidas no Brasil, e são poucas as cultivares disponíveis no mercado brasileiro. Este trabalho teve como objetivo de avaliar a produção de sementes de 20 genótipos arbustivos de feijãovagem, nos sistemas convencional e orgânico, nas condições do Cerrado brasileiro. Foram realizadas avaliações de altura das plantas, número de sementes por vagem, massa de 100 sementes e produtividade. Para altura das plantas e número de sementes por vagem os 20 genótipos se igualaram no sistema de cultivo convencional. Já no sistema orgânico, os 20 genótipos formaram dois grupos distintos quanto à estas variáveis. No sistema convencional não houve diferenças significativas entre os genótipos quanto a massa de 100 sementes, a massa média neste sistema foi de 19,08 g, mas houve diferenças no sistema orgânico. Para produtividade houve diferença significativa entre os genótipos para os dois sistemas de cultivo, orgânico e convencional. A produção de sementes de cultivares arbustivas de feijão-vagem no sistema orgânico mostrou-se viável e promissora. Os genótipos Amarelo Japonês, Hab 1 e Tendergreen Improved destacaram-se entre os mais produtivos nos dois sistemas.

Palavras-chave: Phaseolus vulgaris L.; sustentabilidade; produtividade 


\section{Introduction}

Snap bean, Phaseolus vulgaris L., despite being one of the most consumed vegetables in Brazil, due to its high content of vitamins and minerals, digestive fibers and low caloric value, it has a low number of cultivars adapted to the different production systems (Ramirez et al., 2012). It differs from common beans by its larger pods with a low fiber content that are consumed like vegetables, when they are still immature, non-fibrous and soft. However, when the pods are harvested dry, the beans have culinary characteristics similar to the common beans (Peixoto \& Cardoso, 2016).

As for the growth habit, the snap bean can be classified as undetermined, or climbing and determined, or bush. Cultivars of indeterminate growth have a vegetative apical meristem that allows the continuous growth of plants, with they commonly achieveing higher yields when compared to bush cultivars (Wahome et al, 2013), up to more than $30 \mathrm{t} \mathrm{ha}^{-1}$, as reported by Almeida et al. (2014). However, such cultivars need more intense care regarding their crop management, causing a greater demands on labor, since they need tutoring, and, due to their longer cycle, they are more subject to the incidence of pests and diseases, thus increasing the overall production costs (Wahome et al., 2013; Gomes et al., 2017).

Cultivars of determined growth, also called bush or shrub, have their apexes closed by inflorescences, which originate from the main stem and lateral branches, with a brief flowering period, allowing to concentrate the yield. The smaller cycle saves the use of both soil and labor, contributing to facilitate cultivation and, mainly, reducing the costs, thus increasing the income of the pod producers. Another advantage is the possibility of having a single harvest, ripping the plants out from the field and cutting their pods off, either manually or throught appropriate harvesters (Peixoto \& Cardoso, 2016).

Bush or shrub cultivars were introduced from other countries, starting in the 1980 s. These have contributed to the expansion of snap beans crop in several regions of Brazil, with it standing out as a good low operational cost option for Fall/ Winter in irrigated areas, since they enable the mechanization of most cultivation operations. Moreover, these cultivars produce good quality pods, which in turn has led to the greater demand for this group by producers (Francelino et al., 2011; Andrade et al., 2017; Peixoto \& Cardoso, 2016; Vaz et al., 2017).

To this date, there has been an increase in demand for food produced in organic systems for several reasons, among them are the concern with the environment and with healthier foods, free of synthetic pesticides. This market has grown every year, however, there is a need for both researches and technological development for this productive chain meeting the needs of producers and consumers alike. In Brazil, information about the organic production of snap bean is still scarce (Vidal et al, 2007; Nascimento et al., 2008).

In a study with the production components of bush snap beans, in conventional and organic systems, Gomes et al. (2017) observed that the cycle was shorter in the conventional system and that there was interaction between cultivars and cultivation systems, with the plants having greater development in the organic system, without affecting the yield of marketable pods. Brunner et al. (2014), studied eight snap bean cultivars in an organic system and observed yield results ranging from 9.9 to 14.6 tons of pods per hectare.

Although the introduction of shrub cultivars in Brazil is recent, its demand has grown, and it is of fundamental importance to make suitable cultivars available, both for the organic and conventional systems. In this sense, the objective of this study was to evaluate snap bean genotypes produced in conventional and organic systems.

\section{Materials and Methods}

Two experiments were performed in 2016, between April and August, in the Olericulture and Horticulture sector of the Experimental Station of Anápolis (EEA) from EMATER-Goiás, in Anápolis-GO. The area is located at latitude 16019'48" $\mathrm{S}$, longitude $48.58^{\prime} 23^{\prime \prime} \mathrm{W}$ and altitude of $1,032 \mathrm{~m}$. One of the experiments with snap beans was in an organic system while the other was in a conventional system, aiming at seed production. The local soil is an Ultisol, or red Latosol according to Embrapa (2006); and by Köppen classification, the climate of the region is AW, with well-defined periods of drought and rain and the dry spell occurring during the rainy season.

The experiments were located in two distinct areas, one which has been managed, in conventional cultivation, and the other one organically managed, for over 15 years. The randomized blocks experimental design was employed in each experiment, with treatments consisting of 20 bush genotypes of snap beans (Amarelo Japonês, Commodore Improved, Contender, Delinel, Espada Bush, Festina, Hab 01, Hab 39, Improved Gold Wash, Jade, Kentucky Wonder Bush, Napoli, Provider, Royal Burgundy, Slenderwash, Strike, Stringless Green, Tendergreen, Tendergreen Improved and Turmalina) and three replicates, each plot having four rows three meters long, having been considered as a useful plot the two central rows. Sowing was performed on April 12, 2016. Sprinkler irrigation wasused, in accordance to the crop need, and it was interrupted after $70 \%$ of the pods displayed signs of physiological maturation.

Experiment 1 - Conventional system of snap bean cultivation

Soil analysis resulted in: $\mathrm{pH}$ in $\mathrm{CaCl}_{2}=5.6$; Available $\mathrm{P}$ (Mehlich 1 extractor) $=13.6 \mathrm{mg} \mathrm{dm}^{-3}$, Available $\mathrm{K}=141.0 \mathrm{mg}$ $\mathrm{dm}^{-3}, \mathrm{Ca}+\mathrm{Mg}=3.7 \mathrm{cmol} \mathrm{dm}^{-3}, \mathrm{Al}=0.0 \mathrm{cmol} \mathrm{dm}^{-3}$ and organic matter $=15.0 \mathrm{~g} \mathrm{dm}^{-3}$. The fertilization performed at sowing was held by using $1000 \mathrm{~kg} \mathrm{ha}^{-1}$ of the 02-20-18 formulated. Topdressing fertilization was held with $300 \mathrm{~kg} \mathrm{ha}^{-1}$ of ammonium sulfate, 20 days after sowing.

Sprayings with insecticides were carried out, according to the control level of the pest insects and byusing the recommendation dosage of the manufacturers, for controling Diabrotica speciosa in the initial phase and Bemisia tabaci in the early flowering phase. The control of spontaneous plants 
was carried out by using the active ingredient herbicide fluazifop-p-butyl, with applications in accordance to the recommendation by the manufacturer.

Plucking of the plants was performed manually on August 22, 2016; afterwards, also manually, the trail was built.

\section{Experiment 2 - Organic system of snap bean cultivation}

Management was held in accordance with the Biodynamics certifier and considering the same variables proposed by Vidal et al., (2007). The soil analysis that was held just before the sowing resulted in: $\mathrm{pH}$ in $\mathrm{CaCl}_{2}=5.2$; Available $\mathrm{P}$ (Mehlich 1 extractor) $=6.4 \mathrm{mg} \mathrm{dm}^{-3}$, available $\mathrm{K}=107.0 \mathrm{mg} \mathrm{dm}^{-3}, \mathrm{Ca}+$ $\mathrm{Mg}=2.89 \mathrm{cmol} \mathrm{dm}^{-3}, \mathrm{Al}=0.0 \mathrm{cmol} \mathrm{dm}^{-3}$ and organic matter $=30.0 \mathrm{~g} \mathrm{dm}^{-3}$. The used organic compost was made in the EEA, from the green corn straw and pure poultry manure. The fertilization carried out at sowing was held with $5000 \mathrm{~kg} \mathrm{ha}^{-1}$ of organic compost and $300 \mathrm{~kg} \mathrm{ha}^{-1}$ of Yoorin thermophosphate. Topdressing fertilization was held with $2000 \mathrm{~kg} \mathrm{ha}^{-1}$ of the organic compost. Analysis of the compound resulted in: $\mathrm{pH}$ in water $=6.69 ; \mathrm{K}=8 \mathrm{~g} \mathrm{~kg}^{-1} ; \mathrm{N}=14 \mathrm{~g} \mathrm{~kg}^{-1} ; \mathrm{P}=22 \mathrm{~g} \mathrm{~kg}^{-1}$ and organic matter $=200 \mathrm{~g} \mathrm{~kg}^{-1}$.

All crop treatments held were those allowed for organic cultivation, consisting of weedings employing a hoe, leaving strips of spontaneous vegetation between the rows as the soil vegetation cover. Two sprayings with neem oil and three with neem oil associated with biofertilizer were performed, following the recommendations of the manufacturer, to control the same pests observed in the conventional cultivation system (Diabrotica speciosa and Bemisia tabaci).

Plucking of the plants was performed manually on August 23, 2016; afterwards, also manually, the trail was built.

Evaluated variables for each experiment were:

- Height of plants, performed just before harvesting the dry pods. Obtained by quantifying the mean height of five plants in the plot, corresponding to the distance from the root collar to the end of the main stem, expressed in $\mathrm{cm}$.

- Number of seeds per pod, obtained by counting the number of seeds in samples of ten pods.

- Weight of 100 seeds, expressed in g.

- Yield, obtained by the ratio between the quantification of the weight of all seeds in each plot, expressed in $\mathrm{kg} \mathrm{ha}^{-1}$.

For the joint analysis of the experiment data, the following linear model was adopted: $y_{i j l}=m+t_{i}+d_{j}+d i j+e_{i j l}$, where $i=1,2$, ..., $v$ represents primary treatments (conventional and organic systems); $\mathrm{j}=1,2, \ldots$, represents blocks; $\mathrm{I}=1,2, \ldots$, u represents the secondary treatments (genotypes); yijl is the observed value in the subplot, corresponding to the $\mathrm{i}$-th secondary treatment in the $j$-th block; $m$ is a constant that represents the general mean; bj is the effect of the j-th block; ti is the effect of the $i$-th primary treatment; $t l$ is the effect of the l-th secondary treatment; dil is the effect of the interaction between the i-th primary treatment and the I-th secondary treatment; eijl is the random error attributed to the yijl observation and is considered as the residual component.

Data from each experiment were subjected to analysis of variance and the means were compared by the Scott-Knott test, at the $5 \%$ probability level, aided by the SISVAR ${ }^{\circ}$ program (Ferreira, 2011).

\section{Results and Discussion}

There were significant differences between the two systems, both for plant height and number of seeds per pod. For plant height, no significant difference between genotypes in the conventional system was verified, while for the number of seeds per pod there was a significant difference between genotypes in both systems (Table 1). Cultivars Commodore Improved, Espada Bush, Festina, Jade and Napoli were all equal in height in both cultivation systems, while the others had greater height in the organic system. As for the number of pods per plant, Hab 01 strain and the cultivars Improved Gold Wax, Kentuky Wonder Bush, Tendergreen and Tendergreen Improved had lower means in the conventional system. These two variables express the vigor of the plants verified in the two systems. Plant height in the conventional system ranged from 23.00 to $39.66 \mathrm{~cm}$. The number of seeds per pod, on the other hand, ranged from 5.00 to 6.33. However, in the organic system, a significant difference between the genotypes for these two variables was verified (Table 1).

Regarding plant height in the organic system, two groups were obtained, varying from 31.33 to $57.00 \mathrm{~cm}$. Ten genotypes were classified as larger and ten as smaller. Gomes et al. (2017) concluded that plant height was higher in the organic system, which also occurred in this study.

Superior genotypes regarding plant height were: Amarelo Japonês, Delinel, Hab 01, Hab 39, Kentucky Wonder Bush, Napoli, Royal Burgundy, Strigless Green, Tendergreen and Turmalina.

Amarelo Japonês cultivar had a mean of $57.00 \mathrm{~cm}$ in height, and a tendency to lodging was observed in the field. Very tall plants, when they display a prostrated stem, may have problems in handling and harvesting due to lodging, which can also affect the quality of the pods by the direct contact with the soil. However, the size of the plant, when it is upright, usually leads to higher yield (Gomes et al., 2017).

For the number of seeds per pod in the organic system, classification was also in two groups. Seven out of the 20 genotypes were classified as superior in this variable: Amarelo Japonês, Delinel, Hab 01, Napoli, Tendergreen, Tendergreen Improved and Turmalina.

According to Nascimento et al. (2009), development of cultivars for organic cultivation should not be prioritized. These authors also affirm that it is important to evaluate initially the aptitude for organic cultivation of existing vegetable cultivars, mainly developed aiming at conventional cultivation. For snap bean, the observed was that Delinel, Hab 01, Napoli, Tendergreen and Turmalina were superior in terms of plant height and number of seeds per pod.

There were significant differences between those of the systems for weight of 100 seeds and for yield. The seeds were larger in the organic system, except for the Japanese Japanese cultivar, which was equal in both systems. "The highest yields 
Table 1. Plant height and number of seeds per pod, from bush snap bean genotypes in conventional and organic systems. Anápolis, 2016.

\begin{tabular}{|c|c|c|c|c|}
\hline \multirow{2}{*}{$\begin{array}{l}\text { Evaluated } \\
\text { genotypes }\end{array}$} & \multicolumn{2}{|c|}{ Plant height $(\mathrm{cm})$} & \multicolumn{2}{|c|}{ Number of seeds per pod } \\
\hline & Conventional & Organic & Conventional & Organic \\
\hline Amarelo Japonês & $39.66 \mathrm{aB}$ & $57.00 \mathrm{aA}$ & $6.33 \mathrm{aA}$ & $7.00 \mathrm{aA}$ \\
\hline Commodore Improved & $32.00 \mathrm{aA}$ & $31.33 \mathrm{bA}$ & $5.66 \mathrm{aA}$ & $6.00 \mathrm{bA}$ \\
\hline Contender & $26.00 \mathrm{aA}$ & $35.33 \mathrm{bA}$ & $5.00 \mathrm{bA}$ & $5.33 \mathrm{bA}$ \\
\hline Delinel & $34.00 \mathrm{aB}$ & $50.66 \mathrm{aA}$ & $5.33 \mathrm{bB}$ & $6.66 \mathrm{aA}$ \\
\hline Espada Bush & $33.00 \mathrm{aA}$ & $33.33 \mathrm{bA}$ & $5.33 \mathrm{bA}$ & $6.00 \mathrm{bA}$ \\
\hline Festina & $28.66 \mathrm{aA}$ & $37.33 \mathrm{bA}$ & $6.00 \mathrm{aA}$ & $6.00 \mathrm{bA}$ \\
\hline Hab 01 & $30.00 \mathrm{aB}$ & $46.00 \mathrm{aA}$ & $5.66 \mathrm{aB}$ & $6.67 \mathrm{aA}$ \\
\hline Hab 39 & $30.00 \mathrm{aB}$ & $44.00 \mathrm{aA}$ & $5.33 \mathrm{bA}$ & $6.00 \mathrm{bA}$ \\
\hline Improved Gold Wax & $27.33 \mathrm{aB}$ & $39.66 \mathrm{bA}$ & $5.00 \mathrm{bB}$ & $6.00 \mathrm{bA}$ \\
\hline Jade & $29.66 \mathrm{aA}$ & $39.00 \mathrm{bA}$ & $5.66 \mathrm{aA}$ & $6.00 \mathrm{bA}$ \\
\hline Kentucky Wonder Bush & $30.00 \mathrm{aB}$ & 54.33 aA & $5.00 \mathrm{aB}$ & $6.00 \mathrm{bA}$ \\
\hline Napoli & 29.33 aA & 43.66 aA & $6.00 \mathrm{aA}$ & $6.66 \mathrm{aA}$ \\
\hline Provider & $27.33 \mathrm{aB}$ & $41.00 \mathrm{bA}$ & $5.66 \mathrm{aA}$ & $6.33 \mathrm{bA}$ \\
\hline Royal Burgundy & $32.66 \mathrm{aB}$ & $49.33 \mathrm{aA}$ & $6.00 \mathrm{aA}$ & $6.00 \mathrm{bA}$ \\
\hline Slenderwash & $23.66 \mathrm{aB}$ & $35.33 \mathrm{bA}$ & $5.66 \mathrm{aA}$ & $6.00 \mathrm{bA}$ \\
\hline Strike & $26.33 \mathrm{aB}$ & $38.33 \mathrm{bA}$ & $5.66 \mathrm{aA}$ & $6.00 \mathrm{bA}$ \\
\hline Strigless Green & $25.66 \mathrm{aB}$ & 51.66 aA & $5.66 \mathrm{aA}$ & $6.33 \mathrm{bA}$ \\
\hline Tendergreen & $31.33 \mathrm{aB}$ & $46.66 \mathrm{aA}$ & $5.00 \mathrm{bB}$ & $7.00 \mathrm{aA}$ \\
\hline Tendergreen Improved & $28.00 \mathrm{aB}$ & $37.66 \mathrm{bA}$ & $5.66 \mathrm{aB}$ & $6.66 \mathrm{aA}$ \\
\hline Turmalina & $28.00 \mathrm{aB}$ & $44.33 \mathrm{aA}$ & $6.33 \mathrm{aA}$ & $6.66 \mathrm{aA}$ \\
\hline CV \% for systems & \multicolumn{2}{|c|}{28.03} & \multicolumn{2}{|c|}{8.11} \\
\hline CV \% for genotypes & \multicolumn{2}{|c|}{16.07} & \multicolumn{2}{|c|}{7.27} \\
\hline
\end{tabular}

Means followed by the same lowercase letter in the column, and uppercase in the row, do not differ by the Scott-Knott test, at $5 \%$ error probability level.

were obtained in the organic system, except for the cultivars Commodore Improved and Jade, which were indifferent regarding the production systems (Table 2).

In the conventional system there were no significant differences between the genotypes in terms of the weight of 100 seeds, with the mean weight being of $19.08 \mathrm{~g}$; however, in the organic system, there were differences (Table 2). Also in the organic system, weight of 100 seeds was the variable responsible for ranking the genotypes in five groups. Contender was the cultivar with the largest weight of 100 seeds, with a mean of $45.00 \mathrm{~g}$, followed by the Stringless Green cultivar, with $40.00 \mathrm{~g}$ for every 100 seeds. In a third group, in ascending

Table 2. Weight of 100 seeds and seed yield of bush snap bean genotypes in conventional and organic systems. Anápolis, 2016.

\begin{tabular}{|c|c|c|c|c|}
\hline \multirow{2}{*}{$\begin{array}{l}\text { Evaluated } \\
\text { genotypes }\end{array}$} & \multicolumn{2}{|c|}{ Weight of a 100 seeds (g) } & \multicolumn{2}{|c|}{ Yield (kg ha-1) } \\
\hline & Conventional & Organic & Conventional & Organic \\
\hline Amarelo Japonês & $23.33 \mathrm{aA}$ & $28.33 \mathrm{dA}$ & $1511.10 \mathrm{aB}$ & 2777.76 aA \\
\hline Commodore Improved & $21.66 \mathrm{aB}$ & $31.66 \mathrm{dA}$ & $1283.33 \mathrm{aA}$ & $1344.43 \mathrm{bA}$ \\
\hline Delinel & $16.66 \mathrm{aB}$ & $30.00 \mathrm{dA}$ & $938.90 \mathrm{bB}$ & $2127.80 \mathrm{aA}$ \\
\hline Espada Bush & $20.00 \mathrm{aB}$ & $28.33 \mathrm{dA}$ & $994.46 \mathrm{bB}$ & $1850.00 \mathrm{bA}$ \\
\hline Hab 39 & $18.33 \mathrm{aB}$ & $35.00 \mathrm{cA}$ & $577.76 \mathrm{cB}$ & $2427.80 \mathrm{aA}$ \\
\hline Improved Gold Wax & $20.00 \mathrm{aB}$ & $38.33 \mathrm{cA}$ & $533.33 \mathrm{cB}$ & $2172.23 \mathrm{aA}$ \\
\hline Jade & $21.66 \mathrm{aB}$ & $30.66 \mathrm{dA}$ & $1361.10 \mathrm{aA}$ & $1846.46 \mathrm{bA}$ \\
\hline Kentucky Wonder Bush & $15.00 \mathrm{aB}$ & $33.33 \mathrm{cA}$ & $367.76 \mathrm{~dB}$ & $1561.13 \mathrm{bA}$ \\
\hline Napoli & $13.33 \mathrm{aB}$ & $21.66 \mathrm{eA}$ & $550.00 \mathrm{cB}$ & $1855.56 \mathrm{bA}$ \\
\hline Provider & $23.33 \mathrm{aB}$ & $33.33 \mathrm{cA}$ & $550.00 \mathrm{cB}$ & $1494.43 \mathrm{bA}$ \\
\hline Stringless Green & $15.00 \mathrm{aB}$ & $40.00 \mathrm{bA}$ & $216.66 \mathrm{~dB}$ & $1955.53 \mathrm{bA}$ \\
\hline Tendergreen & $20.00 \mathrm{aB}$ & $36.66 \mathrm{cA}$ & $255.53 \mathrm{~dB}$ & $2411.10 \mathrm{aA}$ \\
\hline Tendergreen Improved & $21.66 \mathrm{aB}$ & $30.00 \mathrm{dA}$ & $1455.53 \mathrm{aB}$ & $2372.23 \mathrm{aA}$ \\
\hline Turmalina & $21.66 \mathrm{aB}$ & $36.66 \mathrm{cA}$ & $783.33 \mathrm{cB}$ & $1722.20 \mathrm{bA}$ \\
\hline CV \% for systems & \multicolumn{2}{|c|}{11.42} & \multicolumn{2}{|c|}{26.21} \\
\hline CV \% for genotypes & \multicolumn{2}{|c|}{14.04} & \multicolumn{2}{|c|}{24.62} \\
\hline
\end{tabular}

Means followed by the same lowercase letter in the column, and uppercase in the row, do not differ by the Scott-Knott test at $5 \%$ error probability level. 
order of weight of 100 seeds are the cultivars Hab 01, Hab 39, Improved Gold Wax, Kentucky Wonder Bush, Provider, Tendergreen and Turmalina. This group had means of weight of 100 seeds similar to the values found by Vidal et al. (2007). These authors evaluated the genotypes Coralina, Turmalina, Hab 1, Hab 19, Hab 46 and Hab 39 and verified a variation between 30.3 and $35.3 \mathrm{~g}$ for weight of 100 seeds.

The fact higher means were obtained for weight of 100 seeds in comparison to the literature (Vidal et al., 2007) can be explained by the greater adaptation of genotypes to the organic cultivation system. Moreover, the greater balance of nutrients in the soil converted to organic cultivation may also explain these higher weight of 100 seeds values. Napoli and Slenderwash were shown as inferior regarding this variable.

For yield, there was a significant difference between the genotypes for the two cultivation systems, organic and conventional. In the conventional one, the genotypes Amarelo Japonês, Commodore Improved, Festina, Hab 01, Jade and Tendergreen Improved all stood out in terms of yield, ranging from 1205.53 to $1511.10 \mathrm{~kg} \mathrm{ha}^{-1}$. Genotypes Amarelo Japonês, Hab 01 and Tendergreen Improved also stood out in the organic system, equaling Delinel, Improved Gold Wax, Royal Burgundy, Slenderwash, Tendergreen and Tendergreen Improved, with means ranging from 2127.80 to $2777.76 \mathrm{~kg} \mathrm{ha}^{-1}$. Napoli cultivar was among the least productive in both systems. Higher yield values found in the conventional cultivation system are in agreement with Brunner et al. (2014), who found, in na organic system in Puerto Rico, Panama, yields of marketable pods superior to those found in conventional system. They also agree with Portal et al. (2018), who, studying genotypes of wild bean of indeterminate growth, in the same place, also found better yield performance in organic production system.

Evaluating only the conventional system, in the Cerrado region, Vaz et al. (2017) found yield ranging from 1,536 to $3,398 \mathrm{~kg} \mathrm{ha}^{-1}$. The high incidence and controlling difficulty of Diabrotica speciosa in the initial phase, and of Bemisia tabaci, from the flowering stage onwards, may have been the main responsibles for the low yield, specially in the conventional system, despite the adopted controlling measures using recommended pesticides. In the organic system, probably due to the existence of other plants coexisting in the same environment, such as forage turnip, may have reduced the attack on the snap bean plants by the preference mechanism. In addition, the repellency of neem oil may have helped reducing damage to the organic system.

Although this study did not obtain similar yield to the higher values found by Vaz et al. (2017), the results were much higher than the national mean, which is of $800 \mathrm{~kg} \mathrm{ha}^{-1}$ (Martins et al., 2014). This fact highlights the possibility of growing and producing snap beans seeds in an organic system to meet the growing demand for organic products.

\section{Conclusions}

Production of seeds from bush snap beans cultivars in the organic system proved to be viable and promising, with higher yields than conventional cultivation for most genotypes.
Genotypes Amarelo Japonês, Hab 1 and Tendergreen Improved stood out among the most productive in both systems.

Alternatives for the producer are, in the conventional system, the genotypes Commodore Improved, Festina and Jade, and in the organic system, are the Delinel, Hab 39, Improved Gold Wax, Royal Burgundy, Slenderwax and Tendergreen.

\section{Acknowlodgements}

To the State University of Goiás for granting the master's degree scholarship to the first author.

\section{Literature Cited}

Almeida, S.N.C.; Thiebaut, J.T.L.; Gravina, G. de A.; Araujo, L.C.; Daher, R.F. Avaliação de características morfológicas e agronômicas de linhagens de feijão-de-vagem em Bom Jesus do Itabapoana-RJ, com potencial de recomendação. Vértices, v.16, n.1, p.39-50, 2014. https://doi.org/10.5935/1809-2667.20140003.

Andrade, F.A.; Gonçalves, L.S.A.; Aukuji, A.; Miglioranza, E.; Takahashi, L.S.A.; Balbi-Peña, M.I.; Rodrigues, R. Snap beans for organic farming and evaluation of resistance to the common bacterial blight. Horticultura Brasileira, v.35, n.3, p.385-389., 2017. https:// doi.org/10.1590/S0102-053620170311.

Brunner, B.; Brady, K.; Flores, L.; Beaver, J. S. Yield performance of eight snap bean genotypes grown under an organic management system in the tropics. The Journal of Agriculture of the University of Puerto Rico, v.98, n.1, p.15-20, 2014. https://revistas.upr.edu/ index.php/jaupr/article/view/217/215. 21 Abr. 2018.

Empresa Brasileira de Pesquisa Agropecuária - Embrapa. Centro Nacional de Pesquisa do Solo. Sistema brasileiro de classificação de solos. 2.ed. Rio de Janeiro,Embrapa Solos, 2006. 306p.

Ferreira, D.F. Sisvar: a computer statistical analysis system. Ciência e Agrotecnologia, Lavras, v.35, n.6, p.1039-1042, 2011. https://doi. org/10.1590/S1413-70542011000600001.

Francelino, F. M.A.; Gravina, G. de A.; Manhães, C.M.C.; Cardoso, P.M.R.; Araújo, L.C. de. Avaliação de linhagens de feijão-de-vagem para as regiões Norte e Noroeste Fluminense. Revista Ciência Agronômica. Revista Ciência Agronômica, v.42, n.2, p.554-562, 2011. https://doi.org/10.1590/S1806-66902011000200039.

Gomes, G.R.; Furlan, F.F.; Freiria, G.H.; Gonçalves, L.S.A.; Production components and yield of bushing snap bean in conventional and organic production systems. Semina: Ciências Agrárias, v.38, n.5, p.3353-3362, 2017. https://doi.org/10.5433/16790359.2017v38n5p3353.

Martins, C.C.; Vieira, R.D.; Nascimento, W.M. Produção de sementes de feijão-vagem. In: Nascimento, W.M. (Ed.). Produção de sementes de hortaliças. Brasília: Embrapa, 2014. v. 1, p.205-238.

Nascimento, W.M. Tecnologia de sementes de hortaliças. Brasília: Embrapa Hortaliças, 2009. 432p.

Nascimento, W.M.; Vieira, J.V.; Rezende, F.V.; Reis, A.; Muniz, M.F.B.; Silva, F.N. Organic seed production of carrot in Brazil. Acta Horticulturae, n. 782, p.245-250, 2008. https://doi.org/10.17660/ ActaHortic.2008.782.30. 
Peixoto, N.; Cardoso, A.I.I. Cultura do feijão-vagem In: Nascimento, W.M. (Ed.). Hortaliças Leguminosas. Brasília: Embrapa, 2016. p.102-126.

Portal, R. K. V. P.; Nascimento, W. M.; Vidal, V. L.; Coelho, M.; Peixoto, $N$. Productivity in seeds of the green bean produced under conventional and organic systems. Semina: Ciências Agrárias, v. 39 , n. 4, p. 1389-1396, 2018. https://doi.org/10.5433/16790359.2018v39n4p1389.

Ramírez, N.S.; Estrada, J.A.E.; González, M.T.R.; Montes, E.S. Rendimiento y calidad nutrimental de frijol ejotero en dos ambientes. Revista Fitotecnia Mexicana, v.35, n.4, p.317-323, 2012. http://www.scielo.org.mx/pdf/rfm/v35n4/v35n4a8.pdf. 02 Mai. 2018.
Vaz, D. da C.; Morais Junior, O.P.; Peixoto, N. Agro-morphological characterization and genetic divergence assessment in bush snap bean genotypes. Pesquisa Agropecuária Tropical, v.47, n.2, p.134144, 2017. https://doi.org/10.1590/1983-40632016v4743525.

Vidal, V.L.; Junqueira, A.M.R.; Peixoto, N. Desempenho de feijãovagem arbustivo, sob cultivo orgânico em duas épocas. Horticultura Brasileira, v.25, n.1, p.10-14, 2007. https://doi. org/10.1590/S0102-05362007000100003.

Wahome, S.W.; Kimani, P.M.; Muthomi, J.W.; Narla, R.D. Quality and yield of snap bean lines locally developed in Kenya. International Journal of Agronomy and Agricultural Research, v.3, n.7, p.1-10, 2013. http://www.innspub.net/wp-content/uploads/2013/07/ IJAAR-V3No7-p1-10.pdf. 02 May. 2018. 